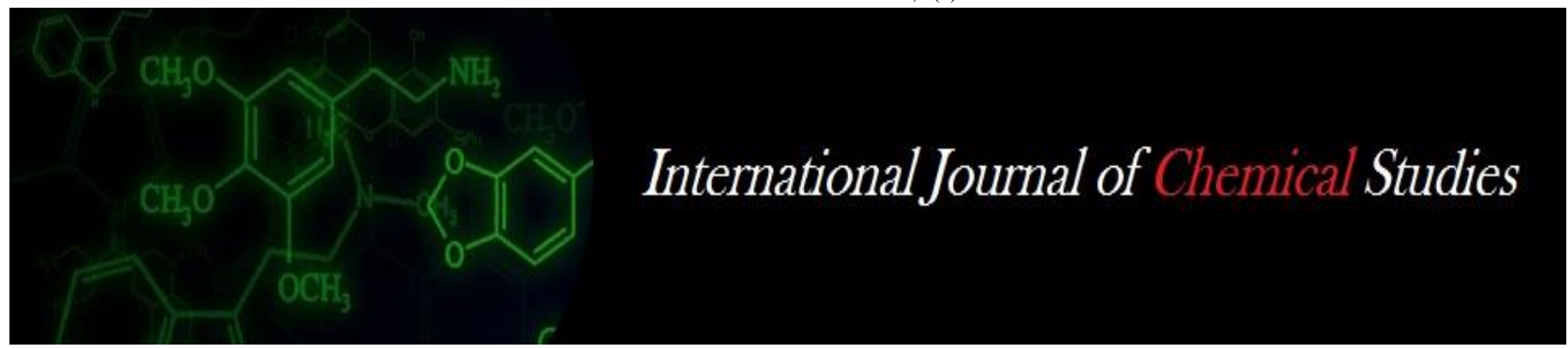

P-ISSN: 2349-8528

E-ISSN: 2321-4902

IJCS 2020; 8(1): 2396-2400

(C) 2020 IJCS

Received: 25-11-2019

Accepted: 27-12-2019

Kiran Yadav

Ph.D. Scholar, Department of Soil Science \& Agricultural

Chemistry, College of

Agriculture, JAU, Junagadh,

Gujarat, India

\section{SR Naga}

Professor \& Head (Retd.),

Department of Soil Science \& Agricultural Chemistry,

SKNAU, Jobner, Rajasthan, India

\section{Sheetal Yadav}

Ph.D. Scholar, Department of Soil Science \& Agricultural Chemistry, SKRAU, Bikaner,

Rajasthan, India
Corresponding Author: Kiran Yadav

Ph.D. Scholar, Department of Soil Science \& Agricultural Chemistry, College of

Agriculture, JAU, Junagadh, Gujarat, India

\section{Impact of phosphorus and sulphur on nutrient content and uptake by clusterbean}

\author{
Kiran Yadav, SR Naga and Sheetal Yadav
}

DOI: https://doi.org/10.22271/chemi.2020.v8.i1aj.8627

\begin{abstract}
A field experiment was conducted at Agronomy farm, S.K.N. College of Agriculture, Jobner, Jaipur during kharif, 2017. The experiment consisted 16 treatment combinations comprising of four levels each of phosphorus $\left(0,20,40\right.$ and $\left.60 \mathrm{~kg} \mathrm{P}_{2} \mathrm{O}_{5} \mathrm{ha}^{-1}\right)$ and sulphur $\left(0,20,40\right.$ and $\left.60 \mathrm{~kg} \mathrm{~S}^{-1}\right)$ was laid out in randomized block design and replicated thrice. Clusterbean variety RGC-1038 was used as a test crop. The results indicated that the application of phosphorus @ $40 \mathrm{~kg} \mathrm{ha}^{-1}$ registered significantly maximum increase in content and uptake of nitrogen, phosphorus, potassium and sulphur in seed as well as in straw over control and $\mathrm{P}_{20}$. The treatment $\mathrm{P}_{40}$ and $\mathrm{P}_{60}$ were remained statistically at par. The increasing levels of sulphur upto $40 \mathrm{~kg} \mathrm{ha}^{-1}$ significantly increased the nitrogen, phosphorus, potassium and sulphur content and uptake by seed and straw of clusterbean as compared to control and $\mathrm{S}_{20}$.
\end{abstract}

Keywords: Clusterbean, phosphorus, sulphur, uptake, content

\section{Introduction}

Cluster bean, called as guar is a drought-tolerant annual legume belongs to the family Leguminosae and sub-family Papilionaceae. Root nodules contain nitrogen fixing bacteria and crop residue when ploughed under, improves the yield of succeeding crops. Cluster bean is a good soil restorative crop which can fix about 40 per cent $\mathrm{N}$ in the soil. The primary importance of guar is considered to be the commercial value of its seed gum (galactomannan gum) which is used in sizing textiles and paper as a sticker and in pill formation. Phosphorus stimulates early root development, growth, blooming and aids in seed formation when applied to legumes. It also improves the crop quality and resistance to disease. This is alarming because phosphorus is the backbone of balanced fertilizer use and it occupies a key place in intensive agriculture. The supply of phosphorus to legumes is more important than that of nitrogen because, latter is being fixed by symbiosis with rhizobium bacteria. Thus, it helps in takingmore atmospheric N. In general $\mathrm{S}$ requirement is slightly less than $\mathrm{P}$. It is essential for synthesis of vitamins (biotine and thiamine), $\mathrm{S}$ containing amino acids (cystine, cysteine and methionine) and promotes nodulation in legumes. It helps in chlorophyll formation and encourages vegetative plant growth.

\section{Material and Methods}

The experiment was conducted at Agronomy farm, S.K.N College of Agriculture Jobner, Jaipur (Rajasthan). The Agronomy farm is situated at $75^{\circ} 28^{\prime}$ East longitude and $26^{\circ} 08^{\prime}$ North latitude and $427 \mathrm{~m}$ above mean sea level. This region falls under Agro-climatic zone-IIIA (Semi-Arid Eastern Plains) of Rajasthan. The experimental soil was loamy sand in texture with high infiltration rate and saturated hydraulic conductivity. The experiment consisted 16 treatment combinations comprising of four levels each of phosphorus $\left(0,20,40\right.$ and $\left.60 \mathrm{~kg}_{2} \mathrm{O}_{5} \mathrm{ha}^{-1}\right)$ and sulphur $\left(0,20,40\right.$ and $\left.60 \mathrm{~kg} \mathrm{Sha}^{-1}\right)$ was laid out in randomized block design and replicated thrice. Clusterbean variety RGC-1038 was used as a test crop.

\section{Nutrient content and uptake}

\section{Nutrient content}

The plant samples at harvest of the clusterbean crop from each plot were collected separately and dried in oven at constant temperature of $70{ }^{\circ} \mathrm{C}$, until they obtained constant weight. The dried samples were powdered in a grinder having stainless steel blades to avoid contamination of micronutrients. 
After drying and grinding these samples were analysed for $\mathrm{N}$, $\mathrm{P}, \mathrm{K}$ and S content. The results were expressed as percent $\mathrm{N}, \mathrm{P}$, $\mathrm{K}$ and $\mathrm{S}$ on dry weight basis.

\section{Nutrient uptake}

The uptake of N, P and K in seed and straw were estimated by using the following formula

$$
\begin{aligned}
& \text { Nutrient uptake } \\
& \left(\mathrm{Kg} \mathrm{ha}^{-1}\right)
\end{aligned}=\frac{\text { Nutrient content }(\%) \text { X Yield }\left(\mathrm{kg} \mathrm{ha}^{-1}\right)}{100}
$$

\section{Results and Discussion \\ Nitrogen content}

Nitrogen content in seed and straw

The effect of treatments $(\mathrm{P}, \mathrm{S})$ on nitrogen content in seed and straw is depicted in the table-1.

Effect of phosphorus: The data showed that application of phosphorus significantly increased the $\mathrm{N}$ content in seed and straw of clusterbean. Data revealed that improvement in $\mathrm{N}$ content was progressive and significant due to phosphorus application up to $40 \mathrm{~kg} \mathrm{P}_{2} \mathrm{O}_{5}$ ha $^{-1}$ over control and $20 \mathrm{~kg} \mathrm{P}_{2} \mathrm{O}_{5}$ ha $^{-1}$ by 18.76 and 8.12 percent in seed and 16.19 and 6.45 percent in straw, respectively. However, level $\mathrm{P}_{40}$ and $\mathrm{P}_{60}$ remained statistically at par.

Effect of sulphur: Data further showed that application of sulphur upto $40 \mathrm{~kg} \mathrm{~S}^{-1}$ significantly increased the $\mathrm{N}$ content in seed and straw of clusterbean over control and $20 \mathrm{~kg} \mathrm{~S}^{-1}$ which was higher by 21.94 and 8.96 percent in seed and 21.73 and 9.09 percent in straw, respectively. However, level $\mathrm{S}_{40}$ and $\mathrm{S}_{60}$ remained statistically at par with each other.

\section{Nitrogen uptake by seed and straw}

The effect of treatments $(\mathrm{P}, \mathrm{S})$ on nitrogen uptake by seed and straw is depicted in the table-1.

Effect of phosphorus: Data presented in table-1 indicated that $\mathrm{N}$ uptake by seed and straw of clusterbean increased significantly up to $40 \mathrm{~kg}_{2} \mathrm{O}_{5}$ ha $^{-1}$ being statistically at par with $60 \mathrm{~kg} \mathrm{P}_{2} \mathrm{O}_{5} \mathrm{ha}^{-1}$. Themagnitude of increase in $\mathrm{N}$ uptake with the application of $40 \mathrm{~kg} \mathrm{P}_{2} \mathrm{O}_{5}$ ha $^{-1}$ was recorded as 60.00 and 19.80 percent by seed and 39.62 and 14.48 percent by straw over control and $20 \mathrm{~kg} \mathrm{P}_{2} \mathrm{O}_{5}$ ha $^{-1}$, respectively.

Effect of sulphur: Data presented in same table further indicated that the effect of application of sulphur on $\mathrm{N}$ uptake was found significantly up to $40 \mathrm{~kg} \mathrm{~S} \mathrm{ha}{ }^{-1}$, which was non significantly differed with $60 \mathrm{~kg} \mathrm{~S} \mathrm{ha}^{-1}$. Application of $40 \mathrm{~kg} \mathrm{~S}$ $\mathrm{ha}^{-1}$ significantly increased the $\mathrm{N}$ uptake over control and $20 \mathrm{~kg}$ $S \mathrm{Sa}^{-1}$ by 79.48 and 19.38 percent by seed and 70.41 and 16.73 percent by straw, respectively.

\section{Phosphorus content}

\section{Phosphorus content in seed and straw}

The influence of treatments on the Phosphorus content in seed and straw is depicted in table-2.

Effect of phosphorus: The data given in table- 2 indicated that increasing levels of phosphorus up to $40 \mathrm{~kg} \mathrm{P}_{2} \mathrm{O}_{5} \mathrm{ha}^{-1}$ significantly increased the $\mathrm{P}$ content in seed and straw of clusterbean. Application of $40 \mathrm{~kg} \quad \mathrm{P}_{2} \mathrm{O}_{5} \quad \mathrm{ha}^{-1}$ recorded significantly higher $\mathrm{P}$ content over control and $20 \mathrm{~kg} \mathrm{P}_{2} \mathrm{O}_{5}$ ha $^{-1}$ by 25.44 and 12.63 percent in seed and 21.42 and 8.67 percent in straw, respectively. The level $\mathrm{P}_{40}$ and $\mathrm{P}_{60}$ were differed non significantly.

Effect of sulphur: Data further showed that application of $40 \mathrm{~kg} \mathrm{~S} \mathrm{ha}^{-1}$ significantly enhanced the $\mathrm{P}$ content over control and $20 \mathrm{~kg} \mathrm{~S}^{-1}$ by 20.76 and 9.84 percent in seed and 18.40 and 8.18 percent in straw, respectively. The level $S_{40}$ and $S_{60}$ were differed non significantly.

\section{Phosphorus uptake by seed and straw}

The influence of treatments on the Phosphorus uptake by seed and straw is depicted in table- 2 .

Effect of phosphorus: Data indicated that the $\mathrm{P}$ uptake by clusterbean increased significantly up to $40 \mathrm{~kg} \mathrm{P}_{2} \mathrm{O}_{5}$ ha $^{-1}$. Themagnitude of increase in $\mathrm{P}$ uptake due to application of $40 \mathrm{~kg}_{2} \mathrm{O}_{5}$ ha $^{-1}$ over control and $20 \mathrm{~kg} \mathrm{P}_{2} \mathrm{O}_{5}$ ha $^{-1}$ was higher by 69.28 and 24.73 percent by seed and 46.10 and 16.88 percent by straw, respectively.

Effect of sulphur: Data presented in same table further indicated that the $\mathrm{S}$ uptake by clusterbean was significantly enhanced up to the level of $40 \mathrm{~kg} \mathrm{~S} \mathrm{ha-1}$, which was non significantly differed with $60 \mathrm{~kg} \mathrm{~S} \mathrm{ha}^{-1}$. The application of $40 \mathrm{~kg}$ $S \mathrm{ha}^{-1}$ increased the $\mathrm{S}$ uptake by 77.52 and 20.61 percent by seed and 66.16 and 16.04 percent by straw over control and $20 \mathrm{~kg} \mathrm{~S} \mathrm{ha-1}$, respectively.

\section{Potassium content}

\section{Potassium content in seed and straw}

The impact of application of various levels of $\mathrm{P}$ and $\mathrm{S}$ on the potassium content in seed and straw is presented in table-3.

Effect of phosphorus: The data given in table- 3 showed that increasing levels of phosphorus upto $40 \mathrm{~kg} \quad \mathrm{P}_{2} \mathrm{O}_{5} \quad \mathrm{ha}^{-1}$ significantly increased the $\mathrm{K}$ content in seed and straw of clusterbean. Application of $40 \mathrm{~kg} \mathrm{P}_{2} \mathrm{O}_{5} \mathrm{ha}^{-1}$ resulted in significantly higher $\mathrm{K}$ content over control and $20 \mathrm{~kg} \mathrm{P}_{2} \mathrm{O}_{5} \mathrm{ha}^{-1}$ by 18.44 and 8.08 percent in seed and 24.57 and 7.77 percent in straw, respectively. However, the level $\mathrm{P}_{40}$ and $\mathrm{P}_{60}$ were remained statistically at par with each other.

Effect of sulphur: Data further showed that the application of $40 \mathrm{~kg} \mathrm{~S}^{-1}$ significantly increased the $\mathrm{K}$ content in seed and straw of clusterbean over control and $20 \mathrm{~kg} \mathrm{~S} \mathrm{ha}^{-1}$ by 19.09 and 9.26 percent in seed and 34.52 and 14.72 percent in straw, respectively. However, the level $S_{40}$ and $S_{60}$ were found statistically at par.

\section{Potassium uptake by seed and straw}

The impact of application of various levels of $\mathrm{P}$ and $\mathrm{S}$ on the potassium uptake by seed and straw is presented in table- 3 .

Effect of phosphorus: Data indicated that the K uptake by seed and straw increased significantly with increasing levels of phosphorus up to $40 \mathrm{~kg} \mathrm{P}_{2} \mathrm{O}_{5} \mathrm{ha}^{-1}$, which was statistically at par with $60 \mathrm{~kg} \mathrm{P}_{2} \mathrm{O}_{5} \mathrm{ha}^{-1}$. Themagnitude of percent increase in $\mathrm{K}$ uptake due to application of $40 \mathrm{~kg} \mathrm{P}_{2} \mathrm{O}_{5} \mathrm{ha}^{-1}$ over control and $20 \mathrm{~kg} \mathrm{P}_{2} \mathrm{O}_{5}$ ha $^{-1}$ was 59.62 and 19.76 percent by seed and 49.68 and 15.90 percent by straw, respectively.

Effect of sulphur: Data presented in same table further indicated that the application of sulphur up to $40 \mathrm{~kg} \mathrm{~S} \mathrm{ha}^{-1}$ significantly increased the $\mathrm{K}$ uptake by seed and straw of clusterbean. Application of $40 \mathrm{~kg} \mathrm{~S}^{-1}$ significantly increased 
the $\mathrm{K}$ uptake in seed by 75.43 and 19.76 percent over control and $20 \mathrm{~kg} \mathrm{~S} \mathrm{ha}{ }^{-1}$, respectively. Similarly, the corresponding increase in $\mathrm{K}$ uptake by straw was 88.79 and 23.09 percent, respectively. The level $\mathrm{S}_{40}$ was remained statistically at par with the level $\mathrm{S}_{60}$.

\section{Sulphur content}

\section{Sulphur content in seed and straw}

The effect of $\mathrm{P}$ and $\mathrm{S}$ applied at various levels on sulphur content in seed and straw is presented in table- 4 .

Effect of phosphorus: It is evident from the data that increasing levels of phosphorus up to $40 \mathrm{~kg} \quad \mathrm{P}_{2} \mathrm{O}_{5} \mathrm{ha}^{-1}$ significantly increased the $\mathrm{S}$ content in seed and straw of clusterbean, which was found at par with $60 \mathrm{~kg} \mathrm{P}_{2} \mathrm{O}_{5} \mathrm{ha}^{-1}$. The maximum $\mathrm{S}$ content in seed and straw was observed under $40 \mathrm{~kg} \mathrm{P}_{2} \mathrm{O}_{5} \mathrm{ha}^{-1}$ and registered 30.70 and 11.19 percent higher sulphur content in seed over control and $20 \mathrm{~kg} \mathrm{P}_{2} \mathrm{O}_{5} \mathrm{ha}^{-1}$, respectively. The corresponding increase in straw was 21.48 and 5.75 percent, respectively.

Effect of sulphur: Data further showed that sulphur content in seed and straw tended to increase significantly with increasing levels of sulphur. Significantly higher sulphur content in seed and straw was recorded with application of sulphur up to $40 \mathrm{~kg}$ $\mathrm{S} \mathrm{ha}^{-1}$ over control and $20 \mathrm{~kg} \mathrm{~S} \mathrm{ha}^{-1}$ but being at par with $60 \mathrm{~kg}$ $\mathrm{S} \mathrm{ha}^{-1}$. The significantly highest $\mathrm{S}$ content was recorded under $40 \mathrm{~kg} \mathrm{~S} \mathrm{ha}^{-1}$ and it was higher by 28.44 and 13.74 percent in seed and 21.13 and 12.87 percent in straw, respectively.

\section{Sulphur uptake by seed and straw}

The effect of $\mathrm{P}$ and $\mathrm{S}$ applied at various levels on sulphur uptake by seed and straw is presented in table- 4 .

Effect of phosphorus: Data indicated that $S$ uptake by clusterbean seed and straw increased significantly up to the level of $40 \mathrm{~kg} \mathrm{P}_{2} \mathrm{O}_{5} \mathrm{ha}^{-1}$, being at pat with $60 \mathrm{~kg} \mathrm{P}_{2} \mathrm{O}_{5} \mathrm{ha}^{-1}$. The significant increase in $\mathrm{S}$ uptake by seed due to application of $40 \mathrm{~kg} \mathrm{P}_{2} \mathrm{O}_{5}$ ha $^{-1}$ was 76.04 and 23.35 percent and by straw 45.92 and 13.87 percent over control and $20 \mathrm{~kg} \mathrm{P}_{2} \mathrm{O}_{5} \mathrm{ha}^{-1}$, respectively.

Effect of sulphur: Data presented in same table further indicated that the effect of application of sulphur on $\mathrm{S}$ uptake was observed resulting in significant increase in seed and straw up to $40 \mathrm{~kg} \mathrm{~S} \mathrm{ha-1,} \mathrm{which} \mathrm{was} \mathrm{differed} \mathrm{with} 60 \mathrm{~kg} \mathrm{~S} \mathrm{ha-1}$. Themagnitude of significant increase in $S$ uptake upto $40 \mathrm{~kg} \mathrm{~S}$ ha $^{-1}$ being 87.91 and 23.91 percent by seed and 70.24 and 21.17 percent by straw over control and $20 \mathrm{~kg} \mathrm{~S} \mathrm{ha}^{-1}$, respectively.

\section{Discussion \\ Effect of phosphorus}

Application of phosphorus @ 40kg ha ${ }^{-1}$ registered significantly maximum increase in content and uptake of $\mathrm{N}, \mathrm{P}, \mathrm{K}$ and $\mathrm{S}$ in seed as well as in straw over control and $20 \mathrm{~kg} \mathrm{P}_{2} \mathrm{O}_{5} \mathrm{ha}^{-1}$ (Table1-4). Application of phosphorus increased total biomass (seed and straw) and nutrient (N, P, K and S) content in clusterbean by providing balanced nutritional environment to the plant and higher photosynthetic efficiency. Uptake of nutrients is the function of their concentration in plant, seed and straw yields, the higher concentration of these nutrients coupled with significantly higher seed and straw yield improved the uptake of N, P, K and S. Higher seed and straw yield with higher dose of phosphorus contributed more removal of $\mathrm{N}$ and $\mathrm{P}$ by the crop (Yadav et al., 2014) ${ }^{[13]}$. Similar results were observed by Kumari and Ushakumari (2002) ${ }^{[5]}$, Singh et al., (2009) ${ }^{[10]}$, Wagadre et al., (2010) [ [2], Awomi et al., (2012) ${ }^{[1]}$ and mohammad et al., (2017) in mungbean.

\section{Effect of sulphur}

The nutrient content and uptake by seed and straw were significantly influenced with the application of sulphur (Table 4.7 to 4.10 ). The significantly maximum N, P, K and S content and uptake by seed and straw were recorded with the application of sulphur @ 40 $\mathrm{kg} \mathrm{ha}^{-1}$ as compared to control. This increase in nitrogen content might be due to favourable effect on availability of nitrogen at the higher level of sulphur.

The sulphur fertilization helps in improving the uptake of N, P, $\mathrm{K}$ and $\mathrm{S}$ in the plant due to synergistic effect with these elements. Moreover, it is one of the essential nutrient for plant growth accumulating 0.2 to $0.5 \%$ in plant tissue on dry matter basis. It is also a key ingredient in the formation of chlorophyll and required to synthesis of sulphur containing amino acids such as cystine, cysteine and methionine and building block of protein which might have resulted in turn enhanced growth and development of plant and ultimately resulted into higher uptake of N, P, K and S (Shah et al., 2013). The higher uptake of N, $\mathrm{P}, \mathrm{K}$ and $\mathrm{S}$ may also be due to the accelerated harvest index at higher levels of $\mathrm{S}$ application elaborated the better assimilate portioning towards developing seeds which might have turned into higher yields and ultimately in higher content and uptake of N, P, K and S by the crop. Karche et al., (2012) ${ }^{[4]}$ have also reported significant improvement in concentration and uptake of N, P, K and S in plant with sulphur application @ 40kg ha- ${ }^{-1}$. Similar findings have also been reported by Kaprekar et al., (2003) ${ }^{[3]}$, Sharma and Singh (2004) ${ }^{[9]}$, Nagar and meena (2004) ${ }^{[8]}$, Chandra Deo and Khandelwal (2009) ${ }^{[2]}$ in chickpea and Kuniya et al., (2018) ${ }^{[6]}$.

Table 1: Effect of phosphorus and sulphur on $\mathrm{N}$ content and uptake by seed and straw of clusterbean

\begin{tabular}{|c|c|c|c|c|}
\hline \multirow{2}{*}{ Treatments } & \multicolumn{2}{|c|}{ N concentration (\%) } & N uptake (kg/ha) \\
\cline { 2 - 5 } & Seed & Straw & Seed & Straw \\
\hline \multicolumn{5}{|c|}{ Phosphorus $\left(\mathbf{P}_{2} \mathbf{O}_{5}\right)$} \\
\hline $\mathrm{P}_{0}$ & 3.25 & 1.42 & 27.30 & 31.65 \\
\hline $\mathrm{P}_{20}$ & 3.57 & 1.55 & 36.46 & 38.60 \\
\hline $\mathrm{P}_{40}$ & 3.86 & 1.65 & 43.68 & 44.19 \\
\hline $\mathrm{P}_{60}$ & 3.90 & 1.67 & 45.23 & 45.90 \\
\hline $\mathrm{SEm} \pm$ & 0.05 & 0.02 & 1.09 & 0.80 \\
\hline $\mathrm{CD}(\mathrm{P}=0.05 \%)$ & 0.15 & 0.06 & 3.15 & 2.30 \\
\hline \multicolumn{5}{|c|}{ Sulphur } \\
\hline $\mathrm{S}_{0}$ & 3.19 & 1.38 & 24.81 & 27.18 \\
\hline $\mathrm{S}_{20}$ & 3.57 & 1.54 & 37.30 & 39.68 \\
\hline $\mathrm{S}_{40}$ & 3.89 & 1.68 & 44.53 & 46.32 \\
\hline $\mathrm{S}_{60}$ & 3.93 & 1.69 & 46.02 & 47.15 \\
\hline $\mathrm{SEm}_{ \pm}$ & 0.05 & 0.02 & 1.09 & 0.80 \\
\hline $\mathrm{CD}\left(\mathrm{P}_{\mathbf{y y y y}} 0.05 \%\right)$ & 0.15 & 0.06 & 3.15 & 2.30 \\
\hline
\end{tabular}


Table 2: Effect of phosphorus and sulphur on $\mathrm{P}$ content and uptake by seed and straw of clusterbean

\begin{tabular}{|c|c|c|c|c|}
\hline \multirow{2}{*}{ Treatments } & \multicolumn{2}{|c|}{$P$ concentration $(\%)$} & \multicolumn{2}{|c|}{ P uptake (kg/ha) } \\
\hline & Seed & Straw & Seed & Straw \\
\hline \multicolumn{5}{|c|}{ Phosphorus ( $\left(_{2} \mathrm{O}_{5}\right)$} \\
\hline $\mathrm{P}_{0}$ & 0.334 & 0.196 & 2.80 & 4.36 \\
\hline $\mathrm{P}_{20}$ & 0.372 & 0.219 & 3.80 & 5.45 \\
\hline $\mathrm{P}_{40}$ & 0.419 & 0.238 & 4.74 & 6.37 \\
\hline $\mathrm{P}_{60}$ & 0.421 & 0.246 & 4.88 & 6.75 \\
\hline $\mathrm{SEm} \pm$ & 0.007 & 0.006 & 0.07 & 0.15 \\
\hline $\mathrm{CD}(\mathrm{P}=0.05 \%)$ & 0.021 & 0.016 & 0.21 & 0.43 \\
\hline \multicolumn{5}{|c|}{ Sulphur } \\
\hline $\mathrm{S}_{0}$ & 0.342 & 0.201 & 2.67 & 3.96 \\
\hline $\mathrm{S}_{20}$ & 0.376 & 0.220 & 3.93 & 5.67 \\
\hline $\mathrm{S}_{40}$ & 0.413 & 0.238 & 4.74 & 6.58 \\
\hline $\mathrm{S}_{60}$ & 0.415 & 0.240 & 4.87 & 6.72 \\
\hline SEm \pm & 0.007 & 0.006 & 0.07 & 0.15 \\
\hline $\mathrm{CD}(\mathrm{P}=0.05 \%)$ & 0.021 & 0.016 & 0.21 & 0.43 \\
\hline
\end{tabular}

Table 3: Effect of phosphorus and sulphur on K content and uptake by seed and straw of clusterbean

\begin{tabular}{|c|c|c|c|c|}
\hline \multirow{2}{*}{ Treatments } & \multicolumn{2}{|c|}{ K concentration $(\%)$} & \multicolumn{2}{|c|}{ K uptake (kg/ha) } \\
\hline & Seed & Straw & Seed & Straw \\
\hline \multicolumn{5}{|c|}{ Phosphorus $\left(\mathbf{P}_{2} \mathrm{O}_{5}\right)$} \\
\hline $\mathrm{P}_{0}$ & 0.824 & 1.758 & 6.91 & 39.39 \\
\hline $\mathrm{P}_{20}$ & 0.903 & 2.032 & 9.21 & 50.87 \\
\hline $\mathrm{P}_{40}$ & 0.976 & 2.190 & 11.03 & 58.96 \\
\hline $\mathrm{P}_{60}$ & 0.992 & 2.240 & 11.49 & 61.90 \\
\hline SEm \pm & 0.024 & 0.054 & 0.26 & 1.43 \\
\hline $\mathrm{CD}(\mathrm{P}=0.05 \%)$ & 0.069 & 0.155 & 0.75 & 4.12 \\
\hline \multicolumn{5}{|c|}{ Sulphur } \\
\hline $\mathrm{S}_{0}$ & 0.822 & 1.680 & 6.39 & 33.12 \\
\hline $\mathrm{S}_{20}$ & 0.896 & 1.970 & 9.36 & 50.80 \\
\hline $\mathrm{S}_{40}$ & 0.979 & 2.260 & 11.21 & 62.53 \\
\hline $\mathrm{S}_{60}$ & 0.998 & 2.310 & 11.69 & 64.68 \\
\hline $\mathrm{SEm} \pm$ & 0.024 & 0.054 & 0.26 & 1.43 \\
\hline $\mathrm{CD}(\mathrm{P}=0.05 \%)$ & 0.069 & 0.155 & 0.75 & 4.12 \\
\hline
\end{tabular}

Table 4: Effect of phosphorus and sulphur on S content and uptake by seed and straw of clusterbean

\begin{tabular}{|c|c|c|c|c|}
\hline \multirow{2}{*}{ Treatments } & \multicolumn{2}{|c|}{ S concentration (\%) } & \multicolumn{2}{c|}{ S uptake (kg/ha) } \\
\cline { 2 - 5 } & Seed & Straw & Seed & Straw \\
\hline \multicolumn{5}{|c|}{ Phosphorus $\left(\mathbf{P}_{\mathbf{2}} \mathbf{O}_{5}\right)$} \\
\hline $\mathrm{P}_{0}$ & 0.114 & 0.121 & 0.96 & 2.70 \\
\hline $\mathrm{P}_{20}$ & 0.134 & 0.139 & 1.37 & 3.46 \\
\hline $\mathrm{P}_{40}$ & 0.149 & 0.147 & 1.69 & 3.94 \\
\hline $\mathrm{P}_{60}$ & 0.153 & 0.148 & 1.78 & 4.07 \\
\hline $\mathrm{SEm}+$ & 0.003 & 0.004 & 0.04 & 0.09 \\
\hline $\mathrm{CD}(\mathrm{P}=0.05 \%)$ & 0.009 & 0.010 & 0.11 & 0.27 \\
\hline \multicolumn{5}{|c|}{ Sulphur } \\
\hline $\mathrm{S}_{0}$ & 0.116 & 0.123 & 0.91 & 2.42 \\
\hline $\mathrm{S}_{20}$ & 0.131 & 0.132 & 1.38 & 3.40 \\
\hline $\mathrm{S}_{40}$ & 0.149 & 0.149 & 1.71 & 4.12 \\
\hline $\mathrm{S}_{60}$ & 0.154 & 0.151 & 1.81 & 4.22 \\
\hline $\mathrm{SEm}+$ & 0.003 & 0.004 & 0.04 & 0.09 \\
\hline $\mathrm{CD}(\mathrm{P}=0.05 \%)$ & 0.009 & 0.010 & 0.11 & 0.27 \\
\hline
\end{tabular}

\section{Conclusion}

Application of phosphorus @ 40kg ha ${ }^{-1}$ registered significantly maximum increase in content and uptake of nitrogen, phosphorus, potassium and sulphur in seed as well as in straw over control and $\mathrm{P}_{20}$. The treatment $\mathrm{P}_{40}$ and $\mathrm{P}_{60}$ were remained statistically at par.

Application of $40 \mathrm{~kg} \mathrm{~S} \mathrm{ha}^{-1}$ registered significantly maximum increase in content and uptake of $\mathrm{N}, \mathrm{P}, \mathrm{K}$ and $\mathrm{S}$ in seed as well as in straw of clusterbean over lower levels of sulphur. The treatment $S_{40}$ and $S_{60}$ remained statistically at par with each other.

\section{References}

1. Awomi TA, Singh AK, Kumarm, Bordoloi LJ. Effect of phosphorus, molybdenum and cobalt nutrition on yield and quality of mung bean [Vigna radiata $(\mathrm{L})$ Wilczek] in acidic soil of North-East India. Indian J Hill Farming. 2012; 25(2):22-26.

2. Chandra Deo, Khandelwal RB. Effect of P and S nutrition on yield and quality of chickpea (Cicer arietinum L.). Journal of the Indian Society of Soil Science. 2009; 57:352-356.

3. Kaprekar N, Sasode DS, Patil A. Yield, nutrient uptake and economics of gram as influenced by $\mathrm{P}$ and $\mathrm{S}$ levels and PSB inoculation under irrigated condition. Legume Research. 2003; 26:125-127.

4. Karche RP, Dalwadim R, Patel JC, Gaikwad VP, Panchal DB. Influence of $P$ and $S$ on yield and nutrient uptake by summer cluster bean grown on typic ustochrept of Anand. Asian Journal of Soil Science. 2012; 7:239-241.

5. KumarimS, Ushakumari K. Effect of vermicompost enriched with rock phosphate on the yield and uptake of nutrient in Cowpea (Vigna unguiculata L. Walp). Journal of Tropical Agriculture. 2002; 40:27-30.

6. Kuniya N, Choudhary Neha, Patel S. Effect of sulphur and zinc application on growth, yield attributes, yield and quality of summer cluster bean in light textured soil. International Journal of Chemical Studies. 2018; 6:15291532.

7. Mohammad Irfan, Yadav BL, Ahamad Atik. Effect of phosphorus and bio-organics on yield and soil fertility status ofmungbean [Vigna radiata (L.) Wilczek] under semi- arid condition of Rajasthan, India. International Journal of Current microbiology and Applied Sciences. 2017; 6:1545-1553.

8. Nagar KC, Meena NL. Effect of phosphorus, sulphur and phosphate solubilizing bacteria on yield components, yield and quality of cluster bean [Cyamopsis tetragonoloba (L.) Taub.]. Legume Research. 2004; 27:27-31.

9. Sharma OP, Singh GD. Effect of sulphur and growth substances on yield and quality of cluster bean [Cyamopsis tetragonoloba (L.) Taub.] Environment and Ecology. 2004; 22:746-748.

10. ShahmA, Manaf A, Hussainm, Farooq S, Zafar-ul-Hyam. Sulphur fertilization improves the sesame productivity and economic return under rainfed condition. International Journal of Agriculture and Biology. 2013; 15:1301-1306.

11. Singh SR, Bhatm I, Wani JA, Najar GR. Role of rhizobium and VAM fungi for improvement in fertility and yield of 
green gram under temperature conditions. Journal of Indian Society of Soil Science. 2009; 57:45-52.

12. Wagadre N, PatelmV, Patel HK. Response of summer green gram (Vigna radiata L.) to vermicompost and phosphorus with and without PSB inoculation. State level seminar on organic farming, Navsari, Gujarat, 2010, 111114.

13. Yadav SK, Patel AG, Yadav BL. Yield, quality and soil fertility of cluster bean [Cyamopsis tetragonoloba (L.) Taub] as influenced by various row spacing and levels of phosphorus. Advance Research Journal of Crop Improvement. 2014; 5:101-104. 